\title{
Reading Nostra Aetate in Reverse: A Different Way of Looking at the Relationships Among Religions
}

\section{Peter C. Phan, Georgetown University}

If the adage "The best things come in small packages" is ever true, the Second Vatican Council's declaration Nostra Aetate (NA) surely is an indisputable proof of its truth. This document is neither a "constitution" (dogmatic or pastoral), nor a "decree," but rather a "declaration," the lowest rank of the three types of conciliar documents. Vatican II issued four declarations, the other three-on the mass media (Inter Mirifica), religious liberty (Dignitatis Humanae), and Christian education (Gravissimum Educations). With somewhat of an exception for the declaration on religious liberty, they were quickly forgotten. By contrast, $N A$ went on to produce an enormous impact on the life of the Roman Catholic Church and its theology, and that in spite of the fact that it is composed of only 1,141 words, in 41 sentences and five paragraphs. "Small packages" indeed!

Of course, it may be argued that $N A$ is short because it does not need to provide the theological foundations for its teaching as these have been elaborated at length in the council's other documents such as the dogmatic constitution on the church (Lumen Gentium) and the decree on missionary activity (Ad Gentes). While this is true, still those theological foundations do not explain why the declaration has become the cornerstone of and impetus for radical and unexpected developments in both the practice and the theology of interreligious dialogue in the Catholic Church in the last fifty years. It is safe to assume that when $N A$ was passed by the assembled bishops by a vote of 2221 in favor to 88 against, few of them if any could have foreseen the dramatic impact and the Wirkungsgeschichte of this shortest of all the documents of the council. 
In this essay I will not rehearse the tortuous five-yearlong history of the composition of the document, a story that has been told often, and well. ' What needs to be stressed is that from its conception as a document entitled Decretum de Iudaeis [Decree on the Jews] drafted by the Secretariat for Christian Unity under the leadership of Cardinal Augustin Bea to the final text that was promulgated by Pope Paul VI on October 28, 1965, its birth was never assured. The precariousness of its gestation is well expressed by Cardinal Franz König who said that $N A$ "almost did not happen" and that it was "almost a miracle that it was ever passed." Nor will I survey the history of the impact of $N A$ on the Roman Catholic Church, the other Christian churches, and other religions. Such a history, which would be tantamount to an account of the interreligious dialogue between Christianity as a whole and other religions in the last fifty years, remains to be written. Rather my interest in this essay is to make a thought experiment, which I term "Reading Nostra Aetate in Reverse."

I first explain the nature, necessity, and purpose of this thought experiment. Secondly, I show how reading $N A$ in reverse will radically change the way in which interreligious dialogue is conducted. Thirdly, I argue that this reading of $N A$ is compatible with, or at least does not deny, traditional Christian claims about divine election, revelation, Jesus, the church, and mission.

\footnotetext{
A concise but illuminating account of the history of $N A$ is given by Thomas Stransky, "The Genesis of Nostra Aetate," America (October 24, 2005), 1-4. For another brief account, see History of Vatican II, vol. V, ed. Giuseppe Alberigo; English version, ed., Joseph A. Komonchak (Louvain: Peeters, 1995-2006; Maryknoll, NY: Orbis, 1995-2006), 211-21. A detailed history of the composition of $N A$ is given by John M. Oesterreicher, "Declaration on the Relationship of the Church to Non-Christian Religions: Introduction and Commentary," in Herbert Vorgrimler, ed., Commentary on the Documents of Vatican II, Vol. V (New York: Herder, 1969), 1-154.
}

${ }^{2}$ Franz König, "It Must Be the Holy Spirit," The Tablet 21/28 (2002), 6. 


\section{Are There Non-Christian Religions? A Thought Experiment}

Those of us working all of our lives exclusively in majority-Christian milieus might miss the offensive tone in the title of NA: Declaration on the Church's Relations to NonChristian Religions (Declaratio de ecclesiae habitudine ad religiones non-christianas). The use of "non" as a prefix to refer to others different from oneself is perhaps an unavoidable anthropological and sociological shorthand to distinguish "us" from "them." But the negative naming of the other loses its innocence as an identity marker when it is used by a group that has consistently claimed to be superior to all others in all aspects of life. The "non" then, when applied to others, implies the absence, or at least imperfect presence, of all the things that make this group the norm and standard of perfection for all others. Thus, during the height of empire and colonialism, such sobriquets as "non-Greek," "non-Roman," "non-Persian," "non-Turkish," "non-British,” "non-Russian,” "non-Han" (Chinese), just to cite a few, were powerful weapons in the imperial and colonialist arsenals to categorize other peoples as uncivilized and barbarian who therefore needed to be brought into the fold by means of the mission civilisatrice and often by conquest and subjugation. Such negative designation is by no means a neutral nomenclature but is part and parcel of the imperial politics of difference and power.

In no way am I implying that the bishops at Vatican II in using the expression "non-Christian" to refer to religions other than Christianity were harboring imperialistic ambitions, religious and otherwise. Indeed, after using this negative umbrella term in the title of the document, they go on naming specific religions such as Hinduism and Buddhism, and specific religious groups such as Muslims (not Islam) and Jews (not Judaism). Nevertheless, there are too many commonalities between Christianity and empire-after all it was an imperial religion for nearly two millennia-to dismiss the concerns about religious domination and conquest as overheated conspiracy theorizing or trivial terminological nitpicking. 
On the contrary, what is at stake in this negative naming is, I submit, deeply theological. The thought experiment I am proposing serves to illustrate this point. Imagine you are a member of one of the so-called "non-Christian" religions mentioned by $N A$. How would you self-identify religiously, let's say, on the census form, under the section "Religious Preference"? Is there a box marked "Non-Christian Religion" in addition to, for instance, Hinduism, Buddhism, Judaism, and Islam, that you can tick off? Of course not, since there are no "non-Christian religions" as such anytime, anywhere. And if "non-Christian religions" is used as a collective moniker for all religions except Christianity, only the specificity of Christianity as a religion is officially and publicly recognized, whereas the other religions are lumped together in a generic and undefined heap of the hoi polloi.

Let's pursue the thought experiment further: Suppose you are a Christian living in a Hindu, or Buddhist, or Muslim country and are filling out a census form, and the form does not include the category "Christian" but only "non-Hindu," "non-Buddhist" or "non-Muslim" categories for Christians to self-identify. You would very likely reject this categorization as chauvinistic and are well within your rights to protest such classification as academically inaccurate at best and religiously discriminatory at worst. Indeed, whenever such negative appellation is used, for instance, when proponents of the nationalistic Hindutva ideology called Indian Christians "nonHindu," it was done with the intent to impugn their civic status, question their patriotism, and to discriminate against them.

The crux of the problem is of course not merely lexicology. Rather, beneath this terminological infelicity lies a theological perspective that goes under the name of "fulfillment theology" of religion and was widespread at Vatican II. What is troublesome, especially for believers in other religions, is that Christianity is used as the measure and standard, as the vera religio, to classify and eventually to evaluate other religions. Though $N A$ 's focus is the relation between Christi- 
anity and other religions, these religions are described from the vantage point of Christianity to show how far they line up with it. In fact, it seems that the various religions are listed in the ascending order of the degree of their agreements with Christianity-from the so-called primal religion through Hinduism and Buddhism to Muslims and lastly to Jews. It is perhaps because of this approach that $N A$ does not mention other Indian religions such as Jainism and Sikhism and the Chinese religious traditions such as Confucianism and Daoism, as these religions do not bear significant similarities with Christianity. Be that as it may, clearly the relation between Christianity and non-Christian religions is not conceived of as mutual but only unidrectional, that is, how other religions are related to Christianity, and, as we will see, how they can be "fulfilled" in Christianity, and not the other way round.

Of course, it must be acknowledged that in $N A$ the Church made a complete volte-face in its understanding of its relation to other religions. Just to cite one example: for those who adopt Pope Benedict XVI's "hermeneutics of reform" and reject the "hermeneutics of discontinuity" it would be a herculean feat of mental prestidigitation to argue the continuity between what Pope Eugenius IV declared at the council of Florence about the Jews on February 4, 1442, and what $N A$ asserts in $\$ 4$. Similarly, what $\$ 2$ of $N A$ affirms about primal religions, Hinduism, and Buddhism is simply and utterly beyond the pre-Vatican II ecclesial imagination:

The Catholic Church rejects nothing of what is true and holy in these religions. It has a high regard for the manner of life and conduct, the precepts and doctrines which, although differing many ways from its own teaching, nevertheless often reflect a ray of that truth which enlightens all men and women... Let Christians, while witnessing to their own faith and way of life, acknowledge (agnoscant), preserve (servent) and promote (promoveant) the spiritual and moral good things (bona spiritualia et moralia) as well as the socio-cultural 
values (valores socio-culturales) which are found among non-Christians.

Perhaps it was due to their justly enthusiastic appreciation for these radically positive changes in the attitude of the Catholic Church toward other religions that is marked by genuine respect and readiness to dialogue that church leaders and theologians, and perhaps even members of other religions, did not avert to the latent patronizing tone of $N A$ 's negative naming of other religions. To remove this theological blight it is not enough to tweak the title of the declaration from "nonChristian religions" to "other religions," though that would be a good place to start. The new title signals a Copernican revolution in the way $N A$ is framed. In brief, with the new title "Declaration of the Relations of the Church to Other Religions," Christianity relinquishes its claim to a privileged and superior position vis-a-vis other religions and will consider itself as one religion among other religions. The relation between Christianity and other religions is a genuinely mutual one, where all religions are equally willing to teach and to be taught by one another. This humble acceptance of Christianity of itself as simply one "religion" among many-not even as primus inter pares-entails a reversal of the two-thousand year old apologetics of Christianity as sola vera religio, not only as vera but also as religio, reserving this term exclusively for itself and dismissing other religions as secta or superstitio. Before making a reversal of $N A$ 's perspective on the relation of the church to non-Christian religions and "reading $N A$ in reverse," it is necessary to take a closer look at Vatican II's theology of religion.

\section{Vatican II and the Fulfillment of Non-Christian Religions}

In the aftermath of Vatican II there has been a veritable avalanche throughout the globe of activities and writings, at both the official and grassroots levels, to promote interreligious dialogue in the forms of common living, collaboration for the common good, theological exchange, and spiritual sharing. New theologies of religion have been developed, us- 
ing different paradigms ranging from exclusivism, inclusivism, and pluralism, or Knitter's four types or models, namely, "replacement" (“Only One True Religion”), "fulfillment" ("The One Fulfills the Many"), "mutuality" ("Many True Religions Called to Dialogue"), and "acceptance" ("Many True Religions: So Be It"). These paradigms or models are so wellknown that there is no need to rehearse them here.

It is safe to say that $N A$ 's undergirding theology of religion hovers between "exclusivism" and "inclusivism," with a stronger nod toward the latter. More precisely, it is a "fulfillment" theology of religion (Knitter's second model), a combination of the exclusivist affirmation of the universality and uniqueness of the function of Jesus as the Savior and of the necessity of the church as the instrument of salvation (extra ecclesiam nulla salus) with the inclusivist acknowledgment of the presence of "elements of truth and grace," Karl Rahner's celebrated phrase, in other religions. This theology of religion has its roots in the writings of pre-Vatican II theologians such as Jean Daniélou and Henri de Lubac, and was developed further by Karl Rahner with his emphasis on the presence of the mystery of Christ (and later, he adds, the Holy Spirit) in all religions with his celebrated concept of "anonymous Christianity." This theology of the presence of Christ in all religions other than Christianity was elaborated in another direction by Raimon Panikkar who speaks of "Christ" as the "symbol" of the human-divine-cosmic (cosmotheandric) Mystery present in all religions, which is experienced in the one identical "faith" but expressed in different "beliefs."

It is Rahner's theology of the inclusive presence of Christ outside Christianity that shaped Vatican II's understanding of the relation of the church to other religions. This is obvious not so much in $N A$ as in the decree on the church's missionary activity (Ad Gentes), as its $\$ 9$ makes it abundantly clear:

Through preaching and the celebration of the sacraments, of which the holy Eucharist is the center and 
summit, missionary activity makes Christ present, who is the author of salvation. It purges of evil associations those elements of truth and grace which are found among people, and which are, as it were, a secret presence of God, and it restores them to Christ their source who overthrows the rule of the devil and limits the manifold malice of evil. So, whatever goodness is found in people's minds and hearts, or in the particular customs and cultures of peoples, far from being lost is purified, raised to a higher level and reaches its perfection, for the glory of God, the confusion of the demon, and the happiness of humankind.

That this text is an unambiguous and resounding affirmation of the fulfillment theology of religion leaves no doubt. Phrases such as "elements of truth and grace," "a secret presence of God," "is purified, raised to a higher level, and reaches its perfection" are the shibboleths of fulfillment theology of religion. While it no doubt constitutes an enormous advance on the purely exclusivist theology of religion of ages past, it leads to the kind of unilateral, patronizing, and arrogant view of "nonChristian" religions. In spite of its genuine admiration and respect for other religions, $N A$ seems unable to appreciate the value of other religions except insofar as they contain "elements of truth and grace" that belong by right to Christ (and, by extension, to the church) outside whom they suffer from "the rule of the devil " and "the manifold malice of evil."

In "restoring" these "elements of truth and grace" to Christ as "their source" by means of the church's "missionary activity," "whatever goodness is found in people's minds and hearts, or in the particular customs and cultures of peoples, far from being lost is purified, raised to a higher level and reaches its perfection.” This affirmation sounds at first generous and benevolent toward other religions, but in fact, at least to the ears of believers in other religions, the wall separating this task of purifying, raising to a higher level, and bringing to perfection the "elements of truth and grace" found in other religions and outright supersession by which they are eliminated is 
menacingly thin and porous. Among contemporary Catholic theologians of religion, James Fredericks has made the most scathing critique of this type of fulfillment theology. In his judgment, it is a Christians-talking-to-Christians, in-house discourse; it distorts other religions for Christian purposes; it domesticates differences; and it lessens the urgency of interreligious dialogue and undermines its value.

It is to be noted that what $N A$ says so far about other religions applies only to the so-called primal religions, Hinduism, and Buddhism ( $\$ 1$ and $\$ 2)$. ( $N A$ speaks of Islam and Judaism only in $\$ 3$ and $\$ 4$ respectively.) Though the declaration does not mention other Indian religions such as Jainism and Sikhism and Chinese religious traditions such as Confucianism and Daoism, and other living religions, it is safe to assume that $N A$ 's fulfillment theology applies to them as well. In general, it must be recognized that $N A$ 's apparently favorable attitude toward these religions is likely to be seen as a Trojan horse that Asian religions receive at their own risk of self-destruction. When $N A$ 's assertion about the need for the "elements of truth and grace" of these religions to be purified, raised and perfected in Christianity is coupled with the rhetoric of the Decree on the Church's Missionary Activity about the "rule of the devil" and the "malice of evil" from which these religions must be delivered through Christ and the church's mission, and when a later declaration of the Congregation for the Doctrine of the Faith, Dominus Iesus, asserts that these religions do not contain divine revelation, that "inspiration" cannot be ascribed to their sacred scriptures, and that their followers do not have "faith" but only "belief," it comes as no surprise that Vatican II's fulfillment theology of

${ }^{3}$ See James Fredericks, Buddhists and Christians: Through Comparative Theology to Solidarity (Maryknoll, NY: Orbis Books, 2004), 14-21. Fredericks's critique of fulfillment theology of religion is well-taken. The question of course, is whether all theologies of religion are but iterations of fulfillment theology, or whether there is a form of theology of religion that is genuinely Christian but does not espouse the main tenets of fulfillment theology. This is the direction I attempt to take in this essay.

SCJR 10 (2015) 
religion leaves the believers in Asian religions cold, to put it mildly.

\section{Toward a Kenotic Theology of the Relations Among Religions}

To move beyond Vatican II's fulfillment theology of religion and to develop an alternative theology that helps effectively to implement $N A^{\prime}$ 's exhortation that Christians "acknowledge," "preserve," and "promote" the truths and values of other religions, it would be necessary to adopt a reversal of the council's perspective on other religions, one which may be termed a "kenotic theology of religion," in the mold of Christ's kenosis (self-emptying) affirmed in Philippians 2:7.

I will attempt to outline the contour of such an approach by drawing on the Jewish-Christian dialogue in the last fifty years. The reason for choosing the Jewish-Christian dialogue as resource is that by any standard it is arguably the most theologically advanced and institutionally successful form of interfaith dialogue in the aftermath of Vatican II. This comes as no surprise given the intimate historical and theological connections between Judaism and Christianity, the complex and not rarely tragic relations between them for two millennia, the fact that $N A$ began as a document about the Jews ( De Judaeis), the significant contributions of Pope John Paul II, the many official statements on Jewish-Christian relations, and not least, the immense scholarly and institutional resources that both partners-in-dialogue have at their disposal.

One possible objection against the use of the JewishChristian dialogue as a model for interreligious dialogue in general is that the relation of Christianity to Judaism is said to be unique and therefore cannot be extended to other types of interreligious dialogue. Of course, there is no denying the "unique" character-theological and historical-of the relation between Judaism and Christianity; Judaism, to use John Paul II's expressions, is not "extrinsic" but in a certain way "intrinsic" to Christianity. But whether the uniqueness of this relationship prohibits the applicability of its theology of reli- 
gion to other religions should not be decided a priori and in globo, that is, on the ground that it is unique. Rather the analogical applicability must be assessed in each particular aspect of this theology of religion. Let it be noted in passing that the intimate bond between Judaism and Christianity does not make the understanding of the precise relation between them any easier; on the contrary, it has been made much harder, especially in light of the Christian "teaching of contempt" and the Christian responsibility for the Shoah. Fortunately, the enormous progress that has been accomplished in the last fifty years in both the religious relations between Jews and Christians and the theology of Jewish-Christian dialogue can, in my judgment, form a most helpful basis for constructing a general theology of religion that promotes a reading of $N A$ in reverse.

1. One of the most important elements of the contemporary theology of Jewish-Christian dialogue is the unequivocal rejection of what is termed "supersessionism," the belief that God's covenant with Israel has been "fulfilled" by Jesus and therefore abolished. That covenant is declared "old" and has been replaced the "new" and "better" covenant that God has made in his Son Jesus. As the result, Israel has been superseded by the church, the new and true People of God, the verus Israel. Over and against supersessionism, it is now widely acknowledged that God's covenant with Israel has not been revoked; rather it remains eternally valid. Hence, the fulfillment theology of religion as expounded above does not apply to Judaism. However "fulfillment" is understood, it cannot mean abolition or replacement.

How does this anti-supersessionst theology of Judaism apply other religions? In terms of covenant, it has been shown that for Irenaeus God has made four covenants with humanity, namely, in Adam, in Noah, in Abraham, and in Jesus, and that none of the three covenants preceding the one made in Jesus was abolished by the fourth. If God's covenant with Abraham, and in him with his descendants, has not been abolished, nor even aufgeheben in the Hegelian sense, the same must be said of God's other covenants made with all peoples. In particular, 
the so-called Noachic covenant, which is embodied primarily in peoples' religions, has never been revoked, and remains eternally valid. In this sense therefore, the fulfillment theology of religion must not be applied to them. They have been neither replaced nor abolished by Christianity. In this context it is important to recall the danger I alluded to above, namely, that the line separating the rhetoric of purification, elevation, and perfection as applied by Nostra Aetate and $A d$ Gentes to Asian religions and their actual supersession is perilously thin, and the tendency to cross the line is well-nigh irresistible, and Dominus Iesus is Exhibit A for it.

2. Another positive achievement of the JewishChristian theology is the overcoming of what Jules Isaac calls the "teaching of contempt," part of which is the representation of Judaism at the time of Jesus as a legalistic and ritualistic religion without a soul, and as a result incapable of accepting Jesus' message, and as a sterile religious tradition lacking spiritual substance and vitality. Thanks to recent biblical and historical scholarship on Second Temple Judaism and on early Christianity we can now interpret the invectives present in the gospels against the Pharisees and the "Jews" (hoi iudaior), Paul's contrast between faith and works, and the statement in the Letter to the Hebrews on Jesus' high priesthood in contrast to the priesthood of ancient Israel not as a blanket rejection of God's covenant with Israel because of its alleged defects but in the context of the (at times vitriolic) dispute between rabbinic Judaism and the Jewish followers of Jesus (regarding the correct interpretation of the Torah and the obligatory character of certain Jewish laws such as circumcision, the Sabbath, and kosher foods). Furthermore, we now understand Judaism not just as the Old Testament but as a living, vibrant, historically evolving religion that provides its followers sure guidance in the practice of the way of the covenant.

Similarly, with regard to Asian religions, we have rejected the "teaching of contempt" that Catholic and Protestant missionaries have propagated against them, depicting them as rank superstition, witchcraft, idolatry, immorality, and works 
of the devil. This kind of scurrilous attack filled the pages of early missionaries' descriptions of the religions they encountered in Asia, Africa, and Latin America. To cite just one infamous example, in the so-called Chinese Rites Controversy, ancestor veneration in Asia was severely condemned by various popes, and Catholic missionaries were obligated to take an oath under pain of excommunication to prohibit the converts from practicing it. Of course, some enlightened missionaries have taken a more benign view of this practice not as a religious cult but as acts of purely civil and political import and deemed it acceptable. A more enlightened theology may even discern "elements of truth and grace" in these rites and other practices of other religions, to be purified, perfected and elevated by Christianity. However, under the veneer of missionary and theological accommodation, there lies a thick layer of the "teaching of contempt" not very different from that directed against Judaism.

Fortunately, in recent decades, many Christians who live among the followers of other religions, especially those with the so-called double religious belonging, have come to appreciate, learn from, and be spiritually nourished by their sacred scriptures, their doctrinal teachings, their moral practices, their monastic and ascetic traditions. Furthermore, we have also come to appreciate Asian religions not as outmoded relicts of technologically backward cultures, a view promoted by Enlightenment historians of religion with an anti-religious bias, but as living, vibrant, evolving religious practices of billions of people struggling to find meaning and God in the midst of poverty, oppression, and suffering.

3. Within this theology of the relation between Christianity and Judaism and between Christianity and other religions such as Islam and Asian religious traditions, the role of Christ as the unique and universal savior and of the church as a community of salvation have of course to be understood differently. The role of Christ as unique and universal savior can no longer be interpreted apart from the equally unique and universal role of the Spirit, which are, in Irenaeus's felicitous 
expression, "the two hands" with which God works out God's one plan of salvation in the world, not independently from, much less in opposition to, each other, but, by the same token, not in an identical, uniform manner everywhere and at all times. Thus, both God's Logos and Pneuma can and do function salvifically in history not as parallel agents (since both are agents of God's one economy of salvation) but before, after, with, and outside each other. In this way, all religions, in which God's Logos and Pneuma are actively present, can legitimately be said to be "ways of salvation" together with Christianity, one religion among other religions.

Space does not permit me to elaborate other aspects of the relation between the church and other religions such as mission and interreligious dialogue. But I hope to have shown that the time to read Nostra Aetate in reverse, in which other religions are no longer viewed and called "non-Christians" but in which Christianity, one religion among others, is purified, perfected, and elevated by its encounter with other religions, has indeed come. 